African J. Biol. Sci., 16 (1): 197-206 (2020)

ISSN 1687-4870

e- ISSN 2314-5501 (online)

www.ajbs.journals.ekb.eg

E.mail: aasdjournal@yahoo.com

\title{
Potential enzyme activity of thermophilic bacteria from hot spring in Egypt
}

\author{
Gehad H. Taha*, Einas H. El-Shatoury, Sahar T.M. Tolba and Mohamed K. Ibrahim \\ Department of Microbiology, Faculty of Science, Ain Shams University, Cairo, Egypt. \\ *Email address: gehadhussein517@yahoo.com \\ Gehad.h.microbiology@sci.asu.edu.eg
}

Received: November 2, 2020; Accepted: November 30, 2020; Available Online December 7, 2020

ABSTRACT
This study aims to isolate and identify thermophilic hydrolytic bacteria from hot spring in South Sinai, Egypt for several industrial applications. In this work, 29 bacterial isolates from hot spring in Egypt were isolated and screened for the production of three thermozymes (amylase, cellulase and protease) at different high temperatures. Fifteen isolates were amylase producer, twenty-one were cellulase producer and twelve isolates were protease producer at different high temperatures. Ten bacterial isolates $(34.5 \%)$ produced the three extracellular enzymes. All bacterial isolates were identified phenotypically as Bacillus spp. This study concludes that hot springs in Egypt is a source for the isolation of thermophilic bacteria producing thermostable enzymes.

Keywords: Bacillus spp- hot spring -thermophilic bacteria- thermozymes.

\section{INTRODUCTION}

Extremophiles are microorganisms thriving extreme ecosystems (Aanniz et al., 2015). Extremophilic microorganisms are classified according to the type of extreme condition which they prefer to grow into seven families, thermophiles, psychrophiles, halophiles, acidophiles, alkaliphiles, metalophiles and piezophiles (Gerday, 2002; Gupta et al., 2014). Thermophiles are microorganisms optimally grow at high temperatures more than $45^{\circ} \mathrm{C}$, while hyperthermophiles grow above $80^{\circ} \mathrm{C}$ (Aanniz et al., 2015; Kumar et al., 2019).

Thermophiles are studied due to their potential to produce thermostable enzymes (amylases, proteases, cellulases, xylanases and lipases) and exopolysaccharides (Pinzón-Martínez et al., 2010; Singh et al., 2010; Al-awsy et al., 2017; Suleiman et al., 2020). These thermo-enzymes are not only stable at high temperature but also active under other extreme conditions such as high or low $\mathrm{pH}$, presence of salts and high pressure (Gomes and Steiner, 2004; Kumar et al., 2019).

Thermophilic bacteria are used in bioremediation, improvement the quality of petroleum oil, composting (Rawat et al., 2005; Poli et al., 2009; Lin et al., 2014). Microbial thermozymes have been extensively used in waste management, biofuel, food, paper, detergent, medicinal and pharmaceutical industries, pulp, feeds, starch, textile and used as biocatalysis, biotransformation and biodegradation due to their extreme stability in elevated high temperatures (Kumar et al., 2019). Bacterial $\alpha$-amylase, protease and cellulase enzymes are the most enzymes used in biotechnology processes (Baltaci et al., 2017).

The aim of this study was to isolate thermophilic bacteria, characterize them phenotypically and evaluate their ability to produce thermostable enzymes. Further work needs to be done to study the possible 


\section{Gehad H. Taha et al.}

use of the two isolates in production of thermostable hydrolytic enzymes which have industrial applications.

\section{MATERIALS AND METHODS Sampling site}

Ten soil samples were collected in sterile plastic containers from Pharaoh bath hot spring, South Sinai, Egypt in March 2018, then transferred to the laboratory for analysis. Samples were pooled together, and air dried then stored in $-20{ }^{\circ} \mathrm{C}$.

\section{Isolation of thermophilic bacteria}

The soil samples were diluted and inoculated onto Petri plates containing nutrient agar medium (Techno pharmchem, India). The inoculated plates were incubated at $60^{\circ} \mathrm{Cf}$ or $24-48 \mathrm{~h}$ (Osman et al., 2018). The bacterial colonies developed on the plates were purified by subculturing on nutrient agar media and maintained in $15 \%(\mathrm{v} / \mathrm{v})$ glycerol(Sazakli et al., 2005).

\section{Characterization of thermophilic bacterial isolates}

Morphological characteristics of the isolates were studied on nutrient agar.The colony morphology, i.e., color, size, margin, elevation and Gram stain according to Sandle (2004). Cell morphology and Gram reactions of the isolates were examined by light microscopy (LABOMED, USA).The optimum temperature of growth for each isolate was determined by inoculation onto nutrient broth medium and incubation at 37 , $45,50,55,60,65,70$ and $75^{\circ} \mathrm{C}$ for $24 \mathrm{~h}$. The turbidity obtained after incubation was measured spectrophotometrically at OD600 nm (Unico UV - 2000) (Abu Bakar et al., 2015).

\section{Screening for enzyme activity of the isolates}

Bacterial isolates were screened for amylolytic, proteolytic and cellulolytic
activity.Tests were carried out at four different elevated temperatures of 50, 55, 60 and $65^{\circ} \mathrm{C}$. Amylase was tested by using starch agar mediumas described by Vaidya and Rathore (2015). The pure isolated colonies were inoculated on starch agar plates and incubated for 24-48 h. After incubation, the plates were flooded with iodine solution, a clear zone around the growth indicated the hydrolysis of starch.

Protease was tested on skimmed milk agar medium as described by Carrim et al. (2006). The pure colonies were inoculated on skimmed milk agar plates and incubated for 24-48 h. After incubation, $2.0 \mathrm{ml}$ of $\mathrm{HCl}$ $0.1 \mathrm{~mol} \mathrm{l}^{-1}$ was added to the plates, clear halos around the growth indicated the hydrolysis of casein.

Cellulase was tested on carboxy methyl cellulose medium as described by Amaresan et al. (2014). The pure colonies were inoculated on CMC agar plates and incubated for 24-48 h. After incubation, the plates were flooded by iodine solution, a clear zone around the growth indicated the hydrolysis of cellulose.

\section{Quantitative assay of amylase activity}

Two bacterial isolates were selected for amylase production at $55^{\circ} \mathrm{C}$ for $24 \mathrm{~h}$. The pure isolated colonies were inoculated in amylase production broth medium as described by Kanimozhi et al. (2014). After incubation, the broth was centrifuged at $8.000 \mathrm{rpm}$ for $20 \mathrm{~min}$ and the cell free supernatant was used as crude enzyme for the amylase activity assay. The amylase activity was measured by the glucose released from the starch hydrolysis by DNSA method as described by Karnwal and Nigam (2013). The amylase activity was determined by incubating $0.5 \mathrm{ml}$ of crude enzyme with $1 \mathrm{ml}$ of $1 \%$ soluble starch in $0.1 \mathrm{M}$ of sodium phosphate buffer ( $\mathrm{pH} 7.0$ ) at $50^{\circ} \mathrm{C}$ for $30 \mathrm{~min}$. After incubation, $2 \mathrm{ml}$ of 3,5 dinitro salicylic acid was added and the 


\section{Potential enzyme activity of thermophilic bacteria from hot spring in Egypt}

mixture was boiled for $10 \mathrm{~min}$. The mixture was measured spectrophotometrically at 540 $\mathrm{nm}$. One unit of enzyme activity was defined as the amount of enzyme which releases one $\mu \mathrm{mol}$ of reducing sugar as glucose per min under the assay condition (Ezeji and Bahl, 2006). Amylase activity was determined by the formula of Karnwal and Nigam (2013). All the experiments were performed in triplicates.

\section{RESULTS \\ Isolation of thermophilic bacteria}

A total of 29 isolatesof thermophilic bacteria were recovered from hot spring soil in Egypt. The bacterial isolates were characterized by cultural characteristics and Gram staining. All isolates were Gram positive bacilli, endospore forming rods. Representative Gram stain of two isolates (Ge 1 and Ge 2) is shown in Figure (1), The endospores position is terminal for isolate Ge 1 and central for isolate Ge 2. The color of the colonies was off white and the size of colonies varied from pinpoint to large colonies. The configuration of the isolates was round or concentric. Representative culture characteristics of the bacterial isolates are shown in Figure (2). All isolates were moderate thermophiles, 27 isolates have optimum temperatures of $55^{\circ} \mathrm{C}$ and the two isolates (Ge 1 and Ge 2) have optimum temperatures of $60^{\circ} \mathrm{C}$. All bacterial isolates were identified as Bacillus spp according to morphological characteristics and Gram stain.

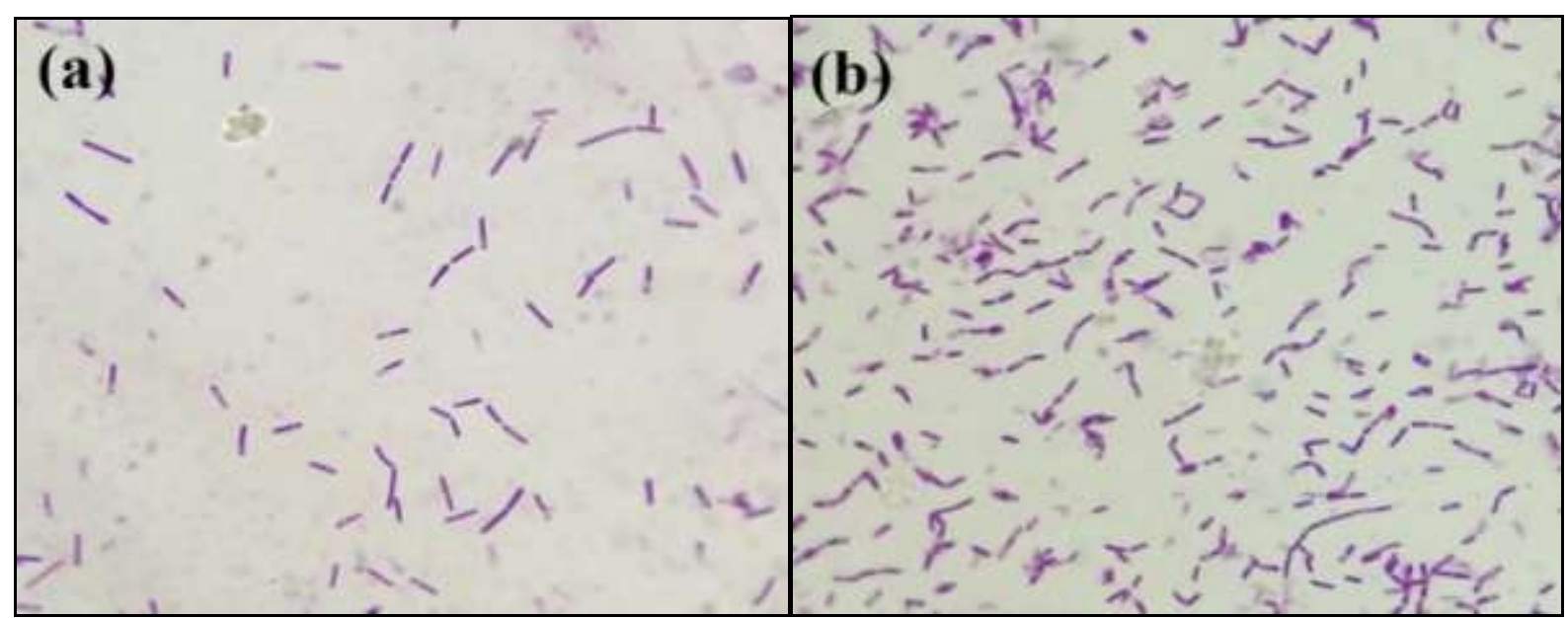

Fig. 1.Gram stain smears of 2thermophilic isolates under light microscope. (a) Ge 1. (b) Ge 2.

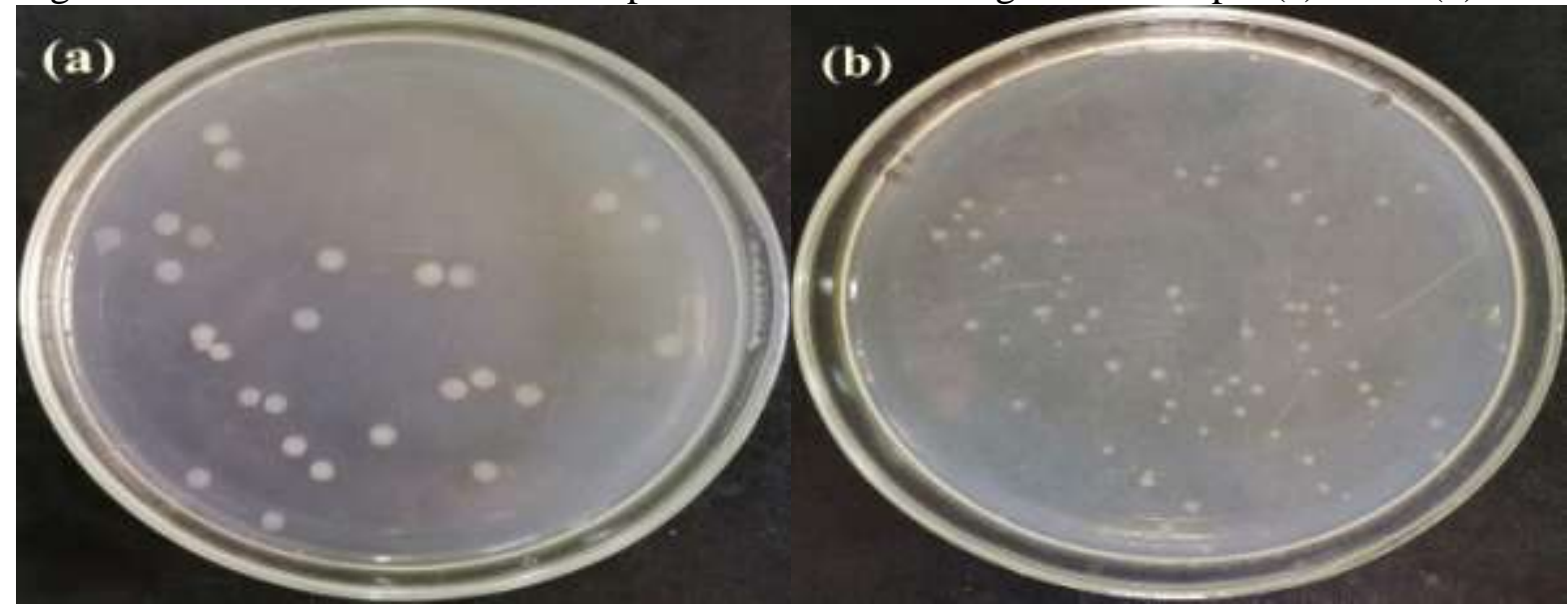

Fig. 2. Culture characteristics of 2 representative thermophilic isolates. (a) Ge 1. (b) Ge 2. 


\section{Gehad H. Taha et al.}

\section{Screening for enzyme activity}

The twenty-nine bacterial isolates

different incubation temperatures. Twentywere screened for amylolytic, cellulolytic two isolates $(75.9 \%)$ produced cellulase. Twelve isolates $(41.4 \%)$ produced protease. and proteolytic activity at different incubation temperatures as shown in

Fig. 3 and 4) and Table (1). Data revealed that 15 isolates $(51.7 \%)$ produced amylase at Fifteen isolates $(51.7 \%)$ co-produced amylase and cellulase, ten isolates $(34.5 \%)$ co-produced the three tested extracellular enzymes.
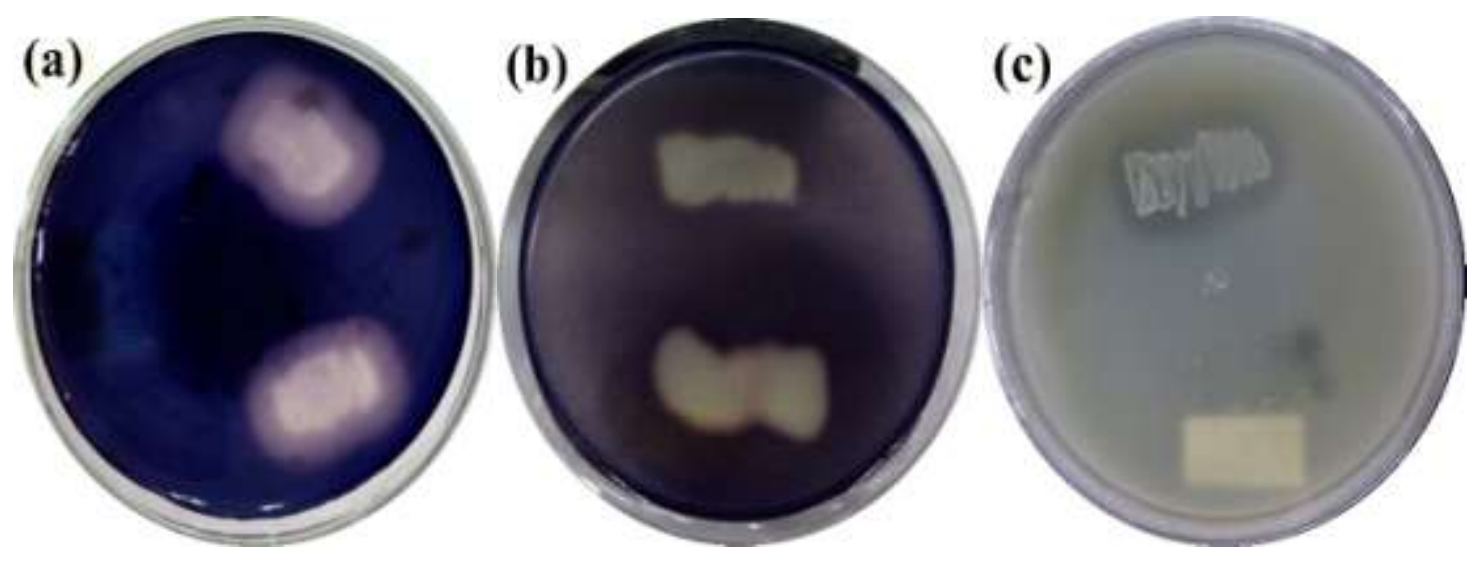

Fig. 3. Production of amylase, cellulase and protease enzymes by the two bacterial isolates. (a) Zone clearance around two isolates for amylase production at $50^{\circ} \mathrm{C}$. (b) Zone clearance around two isolates for cellulase production at $50^{\circ} \mathrm{C}$. (c) Zone clearance around $\mathrm{Ge} 2$ isolate and negative for $\mathrm{Ge} 1$ at $60^{\circ} \mathrm{C}$.

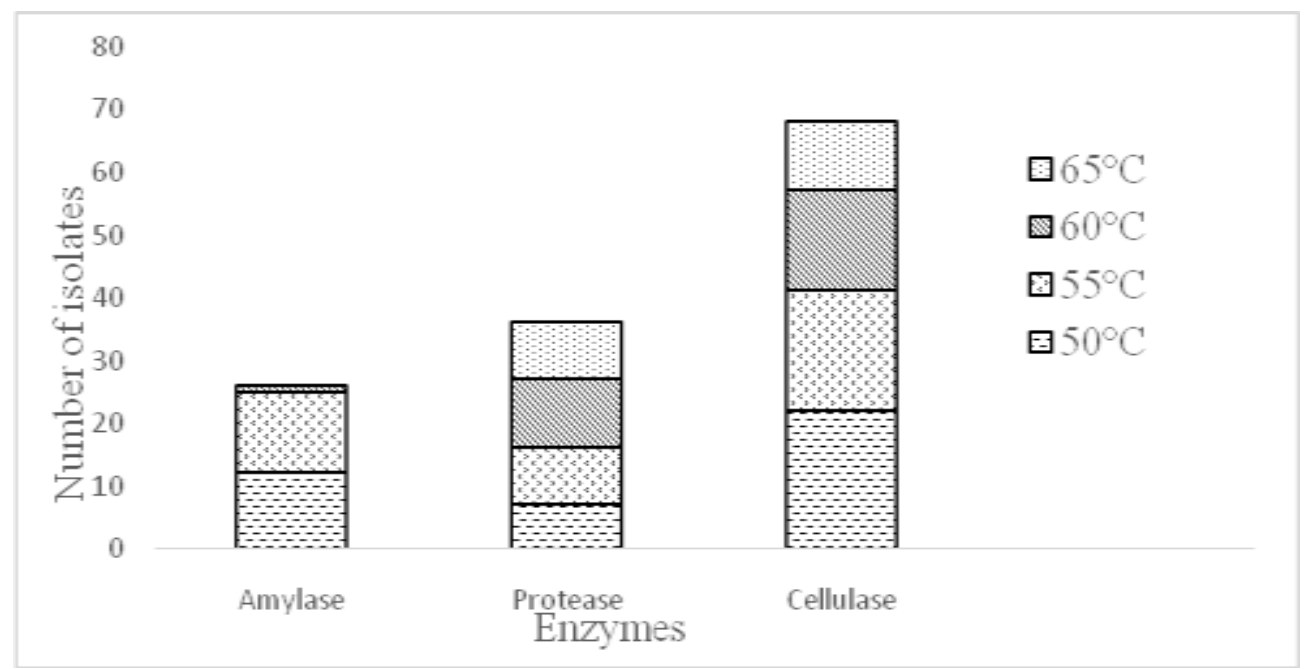

Fig. 4. Production of amylase, cellulase and protease enzymes by the twenty-nine bacterial isolates at 4 different temperatures $\left(50,55,60\right.$ and $\left.65^{\circ} \mathrm{C}\right)$. 


\section{Potential enzyme activity of thermophilic bacteria from hot spring in Egypt}

Table 1. Production of amylase, cellulase and protease enzymes by the twenty-nine bacterial isolates at 4 different temperatures $\left(50,55,60\right.$ and $\left.65^{\circ} \mathrm{C}\right)$.

\begin{tabular}{|c|c|c|c|c|c|c|c|c|c|c|c|c|}
\hline \multirow{3}{*}{$\begin{array}{c}\text { Isolate } \\
\text { code } \\
\text { Ge } 1\end{array}$} & \multicolumn{2}{|c|}{ Amylase } & \multirow[b]{2}{*}{$60^{\circ} \mathrm{C}$} & \multirow[b]{2}{*}{$65^{\circ} \mathrm{C}$} & \multicolumn{2}{|c|}{ Cellulase } & \multirow[b]{2}{*}{$60^{\circ} \mathrm{C}$} & \multirow[b]{2}{*}{$65^{\circ} \mathrm{C}$} & \multicolumn{2}{|c|}{ Protease } & \multirow[b]{2}{*}{$60^{\circ} \mathrm{C}$} & \multirow[b]{2}{*}{$65^{\circ} \mathrm{C}$} \\
\hline & $50^{\circ} \mathbf{C}$ & $5^{\circ} \mathrm{C}$ & & & $50^{\circ} \mathbf{C}$ & $5^{\circ} \mathrm{C}$ & & & $50^{\circ} \mathrm{C}$ & $5^{\circ} \mathrm{C}$ & & \\
\hline & + & + & + & - & + & + & + & - & - & - & - & - \\
\hline Ge 2 & + & + & - & - & + & - & - & - & - & - & + & - \\
\hline PBG-31 & - & + & - & - & + & + & + & - & - & - & - & - \\
\hline PBG-32 & - & - & - & - & - & - & - & - & - & - & - & - \\
\hline PBG-33 & + & - & - & - & + & + & + & + & - & - & - & - \\
\hline PBG-34 & - & + & - & - & + & + & + & + & - & - & - & - \\
\hline PBG-35 & - & - & - & - & - & - & - & - & - & - & - & - \\
\hline PBG-36 & + & + & - & - & + & + & + & + & - & - & + & + \\
\hline PBG-37 & - & - & - & - & + & + & + & + & - & - & - & - \\
\hline PBG-38 & + & + & - & - & + & + & + & + & + & + & + & - \\
\hline PBG-39 & - & + & - & - & + & + & + & + & + & + & + & + \\
\hline PBG-40 & + & + & - & - & + & - & - & - & - & - & - & - \\
\hline PBG-41 & + & + & - & - & + & + & + & + & + & + & + & + \\
\hline PBG-42 & + & + & - & - & + & + & + & + & - & + & + & + \\
\hline PBG-43 & + & + & - & - & + & + & + & + & + & + & + & + \\
\hline PBG-44 & + & + & - & - & + & + & + & + & + & + & + & + \\
\hline PBG-45 & - & - & - & - & + & + & + & + & - & - & - & - \\
\hline PBG-46 & - & - & - & - & + & + & + & - & - & - & - & - \\
\hline PBG-47 & - & - & - & - & + & + & - & - & - & - & - & + \\
\hline PBG-48 & - & - & - & - & + & + & - & - & - & - & - & - \\
\hline PBG-49 & - & - & - & - & - & - & - & - & - & + & + & + \\
\hline PBG-50 & - & - & - & - & - & - & - & - & - & - & - & - \\
\hline PBG-51 & - & - & - & - & + & + & - & - & - & - & - & - \\
\hline PBG-52 & - & - & - & - & - & - & - & - & - & - & - & - \\
\hline PBG-53 & - & - & - & - & - & - & - & - & - & - & - & - \\
\hline PBG-54 & - & - & - & - & + & - & - & - & - & - & - & - \\
\hline PBG-55 & - & - & - & - & - & - & - & - & - & - & - & - \\
\hline PBG-56 & + & - & - & - & + & + & + & - & + & + & + & + \\
\hline PBG-57 & + & + & - & - & + & + & + & - & + & + & + & - \\
\hline
\end{tabular}

Quantitative assay of amylase activity

Two bacterial isolates (Ge 1 and Ge 2) were selected for rhe amylase activity assay. It was observed that the amylase activity of the isolates was 1.690 and 2.425 $\mathrm{IU} / \mathrm{ml}$ for $\mathrm{Ge} 1$ and $\mathrm{Ge} 2$ isolates, respectively.

\section{DISCUSSION}

Hot springs are considered to be the natural habitat of thermophilic bacteria with optimal growth temperatures $>45$ ${ }^{\circ} \mathrm{C}$. Thermophiles represent an important source of biotechnological richness for elevated temperature bioprocesses by their capability of producing a large variety of novel bioactive compounds of biotechnological importance in agriculture, mining, nanotechnology, and other industrial fields.

In this work, bacteria from hot spring in Egypt that produced hydrolytic enzymes 
Gehad H. Taha et al.

have been successfully isolated and identified. successfully Twenty-nine thermophilic bacterial isolates were obtained. All isolates are aerobic Gram positive, spore forming rod shaped and have off white color. The twenty-seven isolates out of 29 isolates have $55^{\circ} \mathrm{C}$ optimum temperature, two isolates have $60^{\circ} \mathrm{C}$ optimum temperature and they are considered moderate thermophilic bacteria according to Rothschild and Mancinelli (2001), and this observation was compatible with the studies about thermophilic microorganisms conducted by Baltaci et al.(2017).The presence of endospore forming bacteria in hot springs is related to their capability to adapt and survive extreme environments (Kambura et al., 2016).

Isolates are belonging to Bacillales according to their Phenotypic characters. Morphological and microscopic characteristics for the bacterial isolates were similar to the characteristics of the genus Bacillus as was described by De Souza and Martins (2001); Mohammad et al. (2017); Gomri et al. (2018). Strains of Bacillus were the most studied bacteria, Maugeri et al. (2001) isolated 87 aerobic,thermophilic and spore-forming bacteria from Eolian Islands (Italy). Moreover, $97.5 \%$ of strains recovered by Aanniz et al. (2015) from Moroccan hot springs were belonging to genus Bacillus. In addition, thermophilic Bacillus was reported by Malkawi and Alomari (2010) from Jordanian hot springs.

Hydrolytic enzymes are not only essential for biochemical reactions within an organism, but their high specificity and catalytic characteristics have enabled them to be used in various industrial sectors for the production of a wide range of products.

Amylase, cellulase and protease are important enzymes in terms of industrial value and they have a wide area of usage in detergent, textile, leather, cosmetics, food, animal feed, pulp and paper industries (Laxman et al., 2005; Kuhad et al., 2011; El-Fallal et al., 2012).

In this study, twenty-nine bacterial isolates were screened for hydrolytic enzymes, amylase, cellulase and protease enzymes. Various extracellular enzymes from thermophilic bacteria isolated from hot springs have also reported by Al-awsy et al. (2017), Megahati et al.(2017) and Alrumman et al.(2018). Twenty-two isolates produced at least one extracellular enzyme at different high temperature. Amylase, cellulase and protease enzymes were produced by 15 isolates $(51.7 \%), 22$ isolates (75.9\%) and 12 isolates (41.4\%), respectively. Fifteen bacterial isolates out of 29 isolates produced amylase and cellulase. Ten isolates out of 29 isolates produced the three tested enzymes.

Amylase activity assay of the two isolates revealed that Bacillus spp Ge 2 gave the maximum amylase of $2.425 \mathrm{IU} / \mathrm{ml}$, while the lowest amylase activity of $1.690 \mathrm{IU} / \mathrm{ml}$ was obtained for Bacillus sp Ge 1. The production of amylase enzyme from Bacillus sp were reported by Bukhari and Rehman (2015) and Salem et al. (2016).

\section{Acknowledgments}

The authors are so grateful to postgraduate studies and research affairs, Faculty of Science, Ain Shams University, Cairo, Egypt for their keen support and providing of possible research grant for obtaining valuable materials and reagents to carry out this work.

\section{Conflict of Interest}

There is no conflict of interest

\section{REFERENCES}

Aanniz, T.; Ouadghiri, M.; Melloul, M.; Swings, J.; Elfahime, E.; Ibijbijen, J.; Ismaili, M.; and Amar, M. (2015). Thermophilic bacteria in Moroccan 


\section{Potential enzyme activity of thermophilic bacteria from hot spring in Egypt}

hot springs, salt marshes and desert soils. Braz. J. Microbiol., 46(2): 443453.

Abu Bakar, A.; Rasol, R.M.; Yahaya, N.; Noor, N.M. and Bin Mohd Ali, M.K.F. (2015). Turbidity method to measure the growth of anaerobic bacteria related to microbiologically influenced corrosion. Solid State Phenom., 227: 298-301.

Al-awsy, M.; Al obiady, S. and Al obaidi, A. (2017). Production of amylase enzyme from thermophilic bacteria using agricultural wastes as a substrate. Aust. J. Basic \& Appl. Sci., 11(October): 158-164.

Alrumman, S.; Mostafa, Y.S.M.; AlQahtani, S. and Taha, T.H.T. (2018). Hydrolytic enzyme production by thermophilic bacteria isolated from Saudi hot springs. Open Life Sci., 13(1): 470-480.

Amaresan, N.; Jayakumar, V. and Thajuddin, N. (2014). Isolation and characterization of endophytic bacteria associated with chilli (Capsicum annuum) grown in coastal agricultural ecosystem. Ind. J. Biotech., 13(April): 247-255.

Baltaci, M.O.; Genc, B.; Arslan, S.; Adiguzel, G. and Adiguzel, A. (2017). Isolation and characterization of thermophilic bacteria from geothermal areas in Turkey and preliminary research on biotechnologically important enzyme production. Geomicrobiol J., 34(1): 53-62.

Bukhari, D.A. and Rehman, A. (2015). Purification and characterization of $\alpha$-amylase from Bacillus subtilis isolated from local environment. Pakistan J. Zool., 47(4): 905-911.

Carrim, A.J I.; Barbosa, E.C. and Vieira, J.D.G. (2006). Enzymatic activity of endophytic bacterial isolates of
Jacaranda decurrens Cham. (Carobinha-do-campo). Braz. Archiv. Biol. Technol., 49(3): 353359.

De Souza, A.N. and Martins, M.L.L. (2001). Isolation, properties and kinetics of growth of a thermophilic Bacillus. Braz. J. Microbiol., 32(4): 271-275.

Derya, Y. and Ahmet, A. (2014). Molecular typing of thermophilic bacilli isolated from different hot springs of Turkey. Res. J. Biotechnol., 9(10): 83-88.

El-Fallal, A.; Abou Dobara, M.; El-Sayed, A. and Omar, N. (2012). Starch and microbial $\alpha$-amylases: from concepts to biotechnological applications. In: C. Chaun-Fa (Ed.), Carbohydrates Comprehensive Studies on Glycobiology and Glycotechnology (Section 5: Biotechnology) (pp. 459-488). Intech, Croatia 2012.

Ezeji, T.C. and Bahl, H. (2006). Purification, characterization, and synergistic action of phytate-resistant $\alpha$-amylase and $\alpha$-glucosidase from Geobacillus thermodenitrificans HRO10. J. Biotechnol., 125(1): 2738.

Gerday, C. (2002). Extremophiles: basic concepts. Knowledge for Substainable Development. In: An Insight into the Encyclopedia of Life Support Systems (Vol. 1). UNESCO Publishing/EOLSS Publishers, Oxford.

Gomes, J. and Steiner, W. (2004). The biocatalytic potential of extremophiles and extremozymes. Food. Technol. Biotech., 42(4): 223235.

Gomri, M.A.; El Moulouk Khaldi, T. and Kharroub, K. (2018). Analysis of the diversity of aerobic, thermophilic endospore-forming bacteria in two Algerian hot springs using cultural 


\section{Gehad H. Taha et al.}

and non-cultural methods. Ann. Microbiol., 68(12): 915-929.

Gupta, G.N.; Srivastava, S.; Khare, S.K. and Prakash, V. (2014). Extremophiles: An: Overview of Microorganism from Extreme Environment. Int. J. Agric. Environ. Biotech., 7(2): 371380.

Kambura, A.K.; Mwirichia, R.K.; Kasili, R.W.; Karanja, E.N.; Makonde, H.M. and Boga, H.I. (2016). Bacteria and Archaea diversity within the hot springs of Lake Magadi and Little Magadi in Kenya. BMC Microbiol., 16(1): 1-12.

Kanimozhi, M.; Johny, M.; Gayathri, N. and Subashkumar, R. (2014). Optimization and production of $\alpha$ amylase from halophilic Bacillus species isolated from mangrove soil sources. J. Appl. Environ. Microbiol., 2(3): 70-73.

Karnwal, A. and Nigam, V. (2013). Production of amylase enzyme by isolated microorganisms and it's application. Int. J. Pharm. Biol. Sci., 3(4): 354-360.

Kuhad, R.C.; Gupta, R. and Singh, A. (2011). Microbial cellulases and their industrial applications. Enzyme Res., 2011(1). doi: $10.4061 / 2011 / 280696$

Kumar, S.; Dangi, A.K.; Shukla, P.; Baishya, D. and Khare, S.K. (2019). Thermozymes: adaptive strategies and tools for their biotechnological applications. Bioresour. Technol., 278: 1-50.

Laxman, R.S.; Sonawane, A.P.; More, S.V.; Rao, B.S.; Rele, M.V.; Jogdand, V.V.; Deshpande, V.V. and Rao, M.B. (2005). Optimization and scale up of production of alkaline protease from Conidiobolus coronatus. Process Biochem., 40(9): 3152-3158.

Lin, Y.; Du, D.; Si, C.; Zhao, Q.; Li, Z. and
Li, P. (2014). Potential biocontrol Bacillus sp . strains isolated by an improved method from vinegar waste compost exhibit antibiosis against fungal pathogens and promote growth of cucumbers. Biol. Control, 71: 7-15.

Malkawi, H.I. and Al-omari, M.N. (2010). Culture-dependent and cultureindependent approaches to study the bacterial and archaeal diversity from Jordanian hot springs. Afr. J. Microbiol. Res., 4(10): 923-932.

Maugeri, T.L.; Gugliandolo, C.; Caccamo, D. and Stackebrandt, E. (2001). A polyphasic taxonomic study of thermophilic bacilli from shallow, marine vents. System. Appl. Microbiol., 24(4): 572-587.

Megahati, R.R.P.; Agustien, A. and Tjong, D.H. (2017). Optimization of bacteria amylase activity from Bacillus licheniformis strain SEM11. Int. J. Curr. Microbiol. App. Sci., 6(11): 2938-2946.

Mohammad, B.T.; Al Daghistani, H.I.; Jaouani, A.; Abdel-Latif, S. and Kennes, C. (2017). Isolation and characterization of thermophilic bacteria from Jordanian hot springs: Bacillus licheniformis and Thermomonas hydrothermalis isolates as potential producers of thermostable enzymes. Int. J. Microbiol., 2017: 1-12.

Osman, Y.; Mowafy, A.; Abdelrazak, A. and El-Mallah, A. (2018). Identification of four thermophilic Geobacillus isolates from hammam pharaon, Sinai, Egypt. J. Agric. Chem. Biotechn., 9(7): 151-157.

Pinzón-Martínez, D.L.; Rodríguez-Gómez, C.; Miñana-Galbis, D.; CarrilloChávez, J.A.; Valerio-Alfaro, G. and Oliart-Ros, R. (2010). Thermophilic bacteria from Mexican thermal 


\section{Potential enzyme activity of thermophilic bacteria from hot spring in Egypt}

environments: Isolation and potential applications. Environ. Technol., 31(8-9): 957-966.

Poli, A.; Salerno, A.; Laezza, G.; di Donato, P.; Dumontet, S. and Nicolaus, B. (2009). Heavy metal resistance of some thermophiles: potential use of $\alpha$-amylase from Anoxybacillus amylolyticus as a microbial enzymatic bioassay. Res. Microbiol., 160(2): 99-106.

Rawat, S.; Adarwal, P.K.; Chaudhary, D.K. and Johry, B.N. (2005). Microbial diversity and community dynamics of mushroom compost ecosystem. In: T. Satyanarayana \& B. N. Johri (Eds.), Microbial diversity: current perspectives and potential applications (pp. 181-206). International Book Distributing Co.

Rothschild, L.J. and Mancinelli, R.L. (2001). Life in extreme environments. Nature, 409(6823): 1092-1101.

Salem, R. Ben; Abbassi, M.S.; Cayol, J.L.; Bourouis, A.; Mahrouki, S.; Fardeau, M.L. and Belhadj, O. (2016). Thermophilic Bacillus licheniformis RBS 5 isolated from hot Tunisian spring co-producing alkaline and thermostable alpha-amylase and protease enzymes. J. Microbiol. Biotechnol. Food Sci., 05(06): 557562.

Sandle, T. (2004). Gram's Stain : history and explanation of the fundamental technique of determinative bacteriology. IST, 54(March 2004): 3-4.

Sazakli, E.; Leotsinidis, M.; Vantarakis, A. and Papapetropoulou, M. (2005). Comparative typing of Pseudomonas species isolated from the aquatic environment in Greece by SDSPAGE and RAPD analysis. J. Appl. Microbiol., 99(5): 1191-1203.

Singh, A. K.; Tripathi, B.M.; Sahay, H.; Singh, R.N.; Kaushik, R.; Saxena, A.K. and Arora, D.K. (2010). Biochemical and molecular characterization of thermo-alkali tolerant xylanase producing bacteria from thermal springs of Manikaran. Indian J. Microbiol., 50(S1): 2-9.

Suleiman, A.D.; Abdul Rahman, N.; Mohd Yusof, H.; Mohd Shariff, F. and Yasid, N.A. (2020). Effect of cultural conditions on protease production by a thermophilic Geobacillus thermoglucosidasius SKF4 isolated from Sungai Klah hot spring Park, Malaysia. Molecules, 25(11): 1-14.

Vaidya, S. and Rathore, P. (2015). Isolation, screening and characterization of amylase producing bacteria from soil of potato dump sites from different regions of Madhya pradesh. In: Int. Conf. Recent Trends Agri. Vet. Life Sci., 1(7). 
Gehad H. Taha et al.

النثاط الانزيمي للبكتيريا المحبة للحرارة من ينبوع ساخن في مصر

جهاد حسين طه ، إيناس حامد الشاطوري ، سحر طلبة محمد ، محمد خالد إبرا هيم

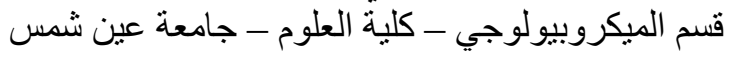

\section{المستخلص}

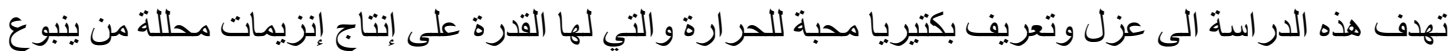

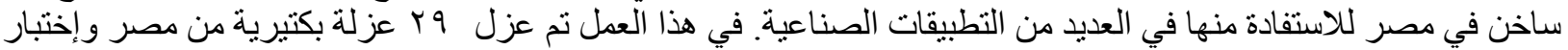

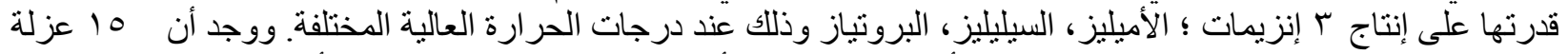

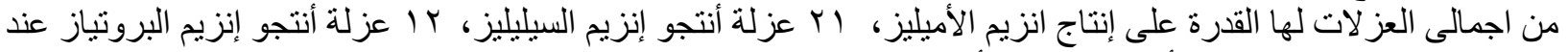

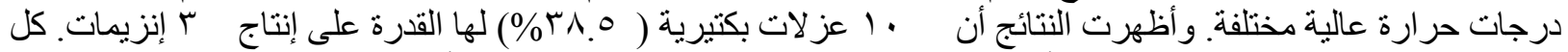

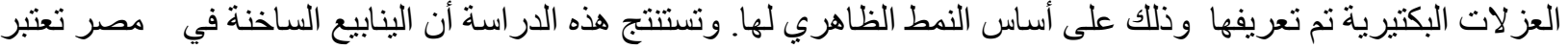

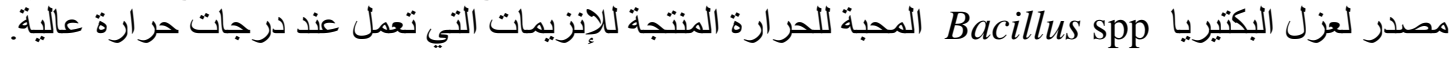

